\title{
The Response of Stevia (Stevia Rebaudiana L.) to Nitrogen and Phosphorous Fertilizer Rates at Menagesha, West Ethiopia
}

\author{
Nebret Tadesse \\ Wondo Genet Agricultural Research Center, EIAR, P.O. Box: 198, Shashemene, Ethiopia.
}

*Corresponding Author: Nebret Tadesse, Wondo Genet Agricultural Research Center, EIAR, P.O. Box: 198, Shashemene, Ethiopia.

\begin{abstract}
A field trial was conducted at Menagesha Cheshire Rehabilitation center to investigate the effect of nitrogen and phosphorus application on growth and yield of stevia during 2014/15 and 2015/16 cropping season in supplementary irrigation. The treatments consisted of four levels of $N(0,23,46$, and $96 \mathrm{~kg} \mathrm{ha-1)}$ and four levels of $P(0,10,20$ and $30 \mathrm{~kg} \mathrm{ha-1)}$ arranged in Randomized Complete Block Design with three replications. The main effect of nitrogen had a significant influence on leaf and above-ground biomass yield of Stevia. The main effect of phosphorous had no significant effect on all of the parameters. The interaction effect of nitrogen and phosphorus were significantly affected number branch per plant, fresh leaf weight and above-ground biomass yield of Stevia. Significantly higher fresh leaf yield (17.18 $t$ ha-1) was obtained from the combined application of 23/30NP $\mathrm{kg}$ ha-land 46/ONP $\mathrm{kg} \mathrm{ha-1.} \mathrm{The} \mathrm{maximum} \mathrm{above-ground} \mathrm{biomass}$ (28.3t ha-1) was recorded from the combined application of 23/30NP $\mathrm{kg}$ ha-1. In conclusion, the results revealed that nitrogen and phosphorous at moderate rates led to a significant increment in growth components and leaf yield of Stevia. Thus, be realized that the application of nitrogen and phosphorous noticeably increases the production of Stevia in the area.
\end{abstract}

Keywords: Stevia, Nitrogen, phosphorous, growth and Stevia leaf yield.

\section{INTRODUCTION}

Stevia rebaudiana Bertoni, known as the "sweetest plant of the world", belongs to the family Asteracea and is native to the South American center of diversity. The world of sweetness has seen a sweeter change in the recent past with the introduction of stevia sugar obtained from leaves of stevia containing compounds about 250 to 300 times sweeter than the table sugar (Kumar, 2002). The substance of interest is stevioside, rebaudioside - A and at least six other compounds that have glucosidal groups attached to a three-carbon ring central structure. Stevioside could be equivalent to the sweetening power of 28 tons per acre of sucrose sugar (Shock, 1982). Though these sugars have sweetening qualities, they have been found to contribute to calories and are not advised for the consumption by diabetic patients.

Growth, yield, and quality of Stevia are not affected by genetic factors, but also environment and one of them is nutrient availability for the plant. The main nutrients required by the plant were nitrogen and phosphorous. Nitrogen is an essential nutrient that could improve growth during the vegetative phase and protein synthesis. According to Hardjowigeno (2010) nitrogen is applied in the plant, which is going to be taken the leaves, because it would make the foliar grow well. Sufficient nitrogen in the soil would make the plants look greener, which means that nitrogen plays its role in forming chlorophyll for the photosynthetic process. Phosphorus is needed for normal growth and development of the plants due to its vital role in chlorophyll synthesis and involvement in various physiological and metabolic processes of the plant. Based on this information, it is presumed that the production of Stevia in Ethiopia is very important however there is lack of cultivation technology on Stevia, therefore this trial aimed to improve Stevia productivity.

\section{Materials AND Methods}

\subsection{The Experimental Site, Design, and Treatments}

The experiment was conducted at Menagesha Cheshire Rehabilitation center, Ethiopia. Menagesha Rehabilitation Center-Cheshire is located $20 \mathrm{~km}$ west of Addis Ababa at $09^{\circ} 03^{\prime} \mathrm{N}$ latitude and $38^{\circ} 34^{\prime}$ 
60 'E longitude with an altitude of 2812 masl. The site receives a mean annual rainfall of $1056 \mathrm{~mm}$ with minimum and maximum temperatures of $6{ }^{\circ} \mathrm{C}$ and $22{ }^{\circ} \mathrm{C}$, respectively. The soil is clay with an average $\mathrm{pH}$ of 5.4. Experimental plots were established in October, 2014/15. The experiment comprised a factorial combination of four levels of $\mathrm{N}\left(0,23,46\right.$, and $\left.96 \mathrm{~kg} \mathrm{ha}^{-1}\right)$ and four levels of $\mathrm{P}$ $\left(0,10,20\right.$ and $\left.30 \mathrm{~kg} \mathrm{ha}^{-1}\right)$ arranged in Randomized Complete Block Design (RCBD) with three replications. The sources of $\mathrm{N}$ and $\mathrm{P}$ were urea $(46 \% \mathrm{~N})$ and triple superphosphate (TSP) (46\% P2O5), respectively. Stevia (rebaudiana Bertoni) was used as a test crop. For seedling preparation, soft stem cutting of $15 \mathrm{~cm}$ length was taken from one-year-old disease-free Stevia mother plants maintained at Wondo Genet Agricultural Research Center botanical garden. Seedlings were raised in the nursery for three months in polyethylene pots. Transplanting was done in October 2015. A spacing of inter-row $50 \mathrm{~cm}$ and intra-row $30 \mathrm{~cm}$ were used for transplanting. Nitrogen fertilizer was applied in three equal splits in each year's (following the treatment), 1/3 during transplanting, and the remaining $\mathrm{N}$ was applied on top dressed in two equal splits at subsequent ratoon plant immediately after the first and second harvest done. The full dose of phosphorus fertilizer was applied at transplanting following the treatment. This was followed and maintained for each cutting throughout the crop season during both the years. First cycle harvesting was done four months after transplanting; the plants were cut uniformly $15 \mathrm{~cm}$ above the ground level whereas the succeeding crops were harvested at a regular interval of three months for two consecutive years. All pertinent data were collected from net plot five selected plants excluding plants from either end of the rows.

\subsection{Soil Analysis}

Soil samples were collected from a depth of $30 \mathrm{~cm}$ before planting at random, and one complete composite sample was prepared to determine the particle size distribution and chemical properties of the soil. Soil texture was determined by Bouyoucos hydrometer method (Day, 1965), Organic matter determined based on the oxidation of organic carbon with acid dichromate medium following the Walkley and Black method And total N determined by Kjeldahl method (Dewis and Freitas, 1970) and available soil P determined using Olsen and Dean (1965) method. Soil pH determined in 1:2.5 soil: water ratio using a glass electrode attached to a digital $\mathrm{pH}$ meter

Data on plant height, number of branches per plant, were recorded from each harvesting cycle and each year and the average value of year was used for analysis. In addition to this, the cumulative value of fresh leaf weight, fresh aboveground biomass, and dry leaf weight in $\mathrm{kg} \mathrm{ha}^{-1}$ was taken three times each year and the values summed up and the average value of two years was used for analysis.

\subsection{Data Analysis}

All data were subjected to analysis of variance (ANOVA) using Statistical Analysis Software (SAS, 2002). The difference among significant treatment means was tested using the least significant difference (LSD) at $5 \%$ level of significance.

\section{RESULT AND DISCUSSION}

\subsection{Major Physico-Chemical Properties of the Soil}

The result of the physical and chemical analysis of experimental soil revealed that the textural class of the surface soil $(0-30 \mathrm{~cm})$ was clay with a particle size distribution of $14 \%$ sand, $28 \%$ silt and $58 \%$ clay. According to Tekalign (1991) and Landon (1991), the chemical analysis showed that the soil was moderately acidic with relatively low nitrogen, low organic matter, and low organic carbon and high available phosphorus. The available $\mathrm{P}$, total $\mathrm{N}$ and organic carbon of the soil were $24 \mathrm{mg} \mathrm{kg}^{-1}$, $0.12 \%$, and $2.3 \%$ respectively. Such soil often responds to P and N application according to Amar (1999) and Landon (1991) respectively (Table 1).

Table1. Pre- transplanting chemical properties of soil (0-30 cm depth)

\begin{tabular}{|c|c|}
\hline Property & Values/type \\
\hline Sand (\%) & 14 \\
\hline Silt (\%) & 28 \\
\hline Clay (\%) & 58 \\
\hline Texture class & Clay \\
\hline $\mathrm{pH}$ & 5.41 \\
\hline CEC micros $/ \mathrm{m}$ & 27.6 \\
\hline
\end{tabular}


The Response of Stevia (Stevia Rebaudiana L.) to Nitrogen and Phosphorous Fertilizer Rates at Menagesha, West Ethiopia

\begin{tabular}{|c|c|}
\hline Total Nitrogen $(\%)$ & 0.12 \\
\hline Organic carbon $(\%)$ & 2.3 \\
\hline Available Phosphorous $\left(\mathrm{mg} \mathrm{kg}^{-1}\right)$ & 24 \\
\hline C: N ratio & 15.2 \\
\hline
\end{tabular}

Table2. Mean square analyses of variance on average growth and yield parameters of stevia as affected by nitrogen and phosphorous in 2014/15 and 2015/16 cropping season

\begin{tabular}{|c|c|c|c|c|c|c|}
\hline Source of Variation & DF & PH & NBPP & FLW $\left(\mathrm{t} \mathrm{ha}^{-1}\right)$ & DLW $\left(\mathrm{t} \mathrm{ha}^{-1}\right)$ & ${\text { FAGB }\left(\mathrm{t} \mathrm{ha}^{-1}\right)}$ \\
\hline Replication & 2 & 0.11 & 2.31 & 6680776.8 & 560003.6 & 13275052.3 \\
\hline Nitrogen & 3 & $2.45 \mathrm{~ns}$ & $34.97 \mathrm{~ns}$ & $13765279.7^{*}$ & $2169765.7^{*}$ & $32976995.3^{*}$ \\
\hline Phosphorous & 3 & $7.81 \mathrm{~ns}$ & $13.92 \mathrm{~ns}$ & $2671301.6 \mathrm{~ns}$ & $564407.4 \mathrm{~ns}$ & $19712119.4 \mathrm{~ns}$ \\
\hline N x P & 9 & $9.71 \mathrm{~ns}$ & $54.57^{*}$ & $11437225.3 *$ & $622186.54 \mathrm{~ns}$ & $27809165.8^{*}$ \\
\hline Error & 30 & 4.96 & 13.6 & 4903089.8 & 298157.16 & 8300903.3 \\
\hline CV\% & & 7.04 & 9.8 & 14.6 & 13.2 & 12.92 \\
\hline
\end{tabular}

$*$ Significant at $p<0.05, n s=$ Not Significant at $p<0.05, P h=$ Plant height, NBPP=Number of branch per plant, $F L W=$ fresh leaf weight, FAGB =Fresh aboveground biomass weight, and DLW= Dry leaf weight

\subsection{Plant Height and Number of Primary Branch Per Plant}

The main effect, as well as the interaction effect of $\mathrm{N}$ and $\mathrm{P}$, did not show a significant difference $(\mathrm{P}>0.05)$ on the plant height of Stevia (Table 2). The interaction effect of nitrogen and phosphorous on the number of primary branch per plant were significant $(\mathrm{P}<0.05)$; however the main effect of nitrogen and Phosphorous didn't affect the number of primary branch per plant (Table2). Maximum number of primary branch per plant $\left(44\right.$ plant $\left.^{-1}\right)$ was obtained in a response of combined application of 69/20 NP kg ha ${ }^{-1}$ which was statistically parity with number of primary branch per plant (39),(39),(42),(41) \& (42) obtained at the combined application of 23/10NP kg ha', 23/20 $\mathrm{NPkgha}^{-1}$, 23/30 NPkgha ${ }^{-1}, 46 / 0 \mathrm{NPkgha}^{-1}, 46 / 10 \mathrm{NPkgha}^{-1}$ respectively, followed by the combined application of $0 \mathrm{~kg} \mathrm{ha}^{-1}+30 \mathrm{Pkg} \mathrm{ha}^{-1}, 69 \mathrm{Nkgha}^{-1}+10 \mathrm{P} \mathrm{kg} \mathrm{ha}^{-1}, 69 \mathrm{Nkgha}^{-1}+30 \mathrm{Pkgha}^{-1}$.

Table3. Main effects of nitrogen and phosphorous on average plant height and Dry leaf weight of Stevia over the 2014/15 and 2015/16 cropping season

\begin{tabular}{|c|c|c|}
\hline Treatments Nitrogen $\left(\mathrm{kg} \mathrm{ha}^{-1}\right)$ & Plant height $(\mathrm{cm})$ & Dry leaf weight $\left(\mathrm{kg} \mathrm{ha}{ }^{-1}\right)$ \\
\hline 0 & 31.4 & $3548 \mathrm{~b}$ \\
\hline 23 & 32.2 & $4511 \mathrm{a}$ \\
\hline 46 & 31.2 & $4115 \mathrm{a}$ \\
\hline 69 & 31.7 & $4371 \mathrm{a}$ \\
\hline LSD & $\mathrm{NS}$ & 455.3 \\
\hline Phosphorous $\left(\mathrm{kg} \mathrm{ha}^{-1}\right)$ & & 3844 \\
\hline 0 & 30.4 & 4244 \\
\hline 10 & 31.9 & 4113 \\
\hline 20 & 32.0 & 4344 \\
\hline 30 & 32.2 & 455.3 \\
\hline LSD 5\% & NS & NS \\
\hline Nitrogen $*$ phosphorous & NS & 13.2 \\
\hline CV\% & 7.04 & \\
\hline
\end{tabular}

Means followed by the same letter within a column are statistically non-significant at $p \leq 0.05$ probability level; $C M=$ Cent meter CV=Coefficient of Variance; $L S D=$ Least Significant Difference

Increasing nitrogen and phosphorus fertilizer on the Stevia plant enhance the number of primary branch per plant over the control. This could be an adequate supply of nitrogen is associated with vigorous vegetative growth and more efficient use of other nutrients. The results are in accordance with the findings of Aladakatti et al. (2012), who reported the increased number of branches and leaves plant ${ }^{-1}$ of Stevia with higher nitrogen and phosphorus. Chalapathi et al. (1999), who also reported an increased number of branches plant ${ }^{-1}$ with nutrient levels of 40:30:45 kg NPK ha ${ }^{-1}$ in sandy loam soils at Bangalore.

\subsection{Fresh Leaf Weight (t ha-1) and Dry Leaf Weight (t ha-1)}

The application of nitrogen was significantly $(\mathrm{P}<0.05)$ affected fresh leaf weight; while no significant variation in fresh leaf weight was observed due to the application of phosphorus. The interaction 
The Response of Stevia (Stevia Rebaudiana L.) to Nitrogen and Phosphorous Fertilizer Rates at Menagesha, West Ethiopia

effect of nitrogen and phosphorus was also found to be significant on fresh leaf weight (Table 2). Although the results were inconsistent, the interaction of nitrogen with phosphorous significantly influenced the fresh leaf weight of stevia. Maximum fresh leaf weight $\left(19.3 \mathrm{t} \mathrm{ha}^{-1}\right)$ was recorded from the combined application of $69 / 20 \mathrm{~kg} \mathrm{ha}^{-1}$ which was in statistical parity with the fresh leaf weight obtained in response to the combined application of 23/10, 23/20, 23/30, 46/0 and 69/10 NP kg ha ${ }^{-1}$. Increasing the rates of nitrogen rates from 0 to $23 \mathrm{~N} \mathrm{~kg}$ ha- 1 with phosphorous rates resulted in higher fresh leaf yield; beyond that showed decreasing trend except for the combined application of $69 / 10$ and 69/20 NP kg ha- ${ }^{-1}$. Increasing nitrogen and phosphorous rates from 0 to 23/30 NP, and 69/20 NP $\mathrm{kg} \mathrm{ha}^{-1}$ resulted in about $39.3 \%$, and $56.4 \%$ additional increased in fresh leaf weight. The significant increase in fresh leaf weight in response to the increased rates of nitrogen and phosphorous application might be ascribed to the increased availability of nitrogen in the soil for uptake by plant roots, which may have sufficiently enhanced vegetative growth through increasing cell division and elongation. The results are in accordance with the findings of Aladakatti et al. (2012), who reported that the highest fresh leaf weight of Stevia with the application of $400 \mathrm{~N} \mathrm{~kg} \mathrm{ha}^{-1}$ with $200 \mathrm{Pkg} \mathrm{ha}^{-1}$ in medium black, clay soil, India. Inugraha et al. (2014) at Malang also reported applying $200 \mathrm{~N} \mathrm{~kg} \mathrm{ha}^{-1}$ with $225 \mathrm{~kg} \mathrm{~K}_{2} \mathrm{O}_{\text {ha }}^{-1}$ obtained higher fresh leaf yield of Stevia.

Applying phosphorous rates with absences of nitrogen resulted in lower fresh leaf weight; this result confirmed that nitrogen fertilizer responded to the crop due to low nitrogen nutrients found in the soil (Table 1).

Table4. Average number of branch per plant, Fresh leaf weight and Fresh Above ground-biomass of Stevia as affected by the interaction effect of nitrogen and phosphorous over the 2014/15 and 2015/16cropping season

\begin{tabular}{|c|c|c|c|c|}
\hline Nitrogen $\left(\mathrm{kg} \mathrm{ha}^{-1}\right)$ & Phosphorous $\left(\mathrm{kg} \mathrm{ha}^{-1}\right)$ & $\begin{array}{c}\text { Number of branch } \\
\text { per plant }\end{array}$ & $\begin{array}{c}\text { Fresh Leaf } \\
\text { Weight }\left(\mathrm{t} \mathrm{ha}^{-1}\right)\end{array}$ & $\begin{array}{l}\text { Fresh Above Ground } \\
\text { Biomass }\left(\mathrm{t} \mathrm{ha}^{-1}\right)\end{array}$ \\
\hline \multirow[t]{4}{*}{0} & 0 & $35 \mathrm{c}-\mathrm{f}$ & $12.33 \mathrm{~cd}$ & $17.95 \mathrm{e}$ \\
\hline & 10 & $33 \mathrm{ef}$ & $13.97 \mathrm{bcd}$ & $17.90 \mathrm{e}$ \\
\hline & 20 & $33 \mathrm{ef}$ & $14.27 \mathrm{bcd}$ & $19.06 \mathrm{e}$ \\
\hline & 30 & $38 b-f$ & $14.53 \mathrm{bcd}$ & $21.71 \mathrm{cde}$ \\
\hline \multirow[t]{4}{*}{23} & 0 & $33 \mathrm{ef}$ & $14.06 \mathrm{bcd}$ & 19.34de \\
\hline & 10 & $39 a-d$ & $15.91 \mathrm{abc}$ & $24.69 \mathrm{abc}$ \\
\hline & 20 & $39 a-d$ & $15.94 \mathrm{abc}$ & $23.37 \mathrm{bcd}$ \\
\hline & 30 & $42 \mathrm{ab}$ & $17.18 \mathrm{ab}$ & $28.34 \mathrm{a}$ \\
\hline \multirow[t]{4}{*}{46} & 0 & $41 \mathrm{abc}$ & $17.19 \mathrm{ab}$ & $24.73 \mathrm{abc}$ \\
\hline & 10 & $42 \mathrm{ab}$ & $15.43 \mathrm{~cd}$ & $22.68 b-e$ \\
\hline & 20 & $32 \mathrm{f}$ & $11.91 \mathrm{~d}$ & $21.78 \mathrm{cde}$ \\
\hline & 30 & $35 c-f$ & $15.85 \mathrm{bc}$ & $22.66 \mathrm{~b}-\mathrm{e}$ \\
\hline \multirow[t]{4}{*}{69} & 0 & $35 c-f$ & $14.57 \mathrm{~cd}$ & $20.75 \mathrm{cde}$ \\
\hline & 10 & $38 b-f$ & $16.15 \mathrm{ab}$ & $23.36 \mathrm{bcd}$ \\
\hline & 20 & $44 \mathrm{a}$ & $19.29 \mathrm{a}$ & $27.20 \mathrm{ab}$ \\
\hline & 30 & $38 b-f$ & $14.92 \mathrm{bcd}$ & $21.36 \mathrm{cde}$ \\
\hline LSD0.05 & 6.15 & 3.69 & 4.80 & \\
\hline $\mathrm{CV} \%$ & 9.8 & 12.9 & 14.6 & \\
\hline
\end{tabular}

Means followed by the same letter within a column are statistically non-significant at $p \leq 0.05$ probability level; $C V=$ Coefficient of Variance; $L S D=$ Least Significant Difference

Significant differences were observed due to the main effect of nitrogen on the dry leaf weight of Stevia. However, the main effect of phosphorous, as well as its interaction with nitrogen, did not affect dry leaf weight. Increasing the rate of nitrogen application from 0 to $23 \mathrm{~kg} \mathrm{~N}^{-1}$ resulted in about a $27.1 \%$ additional increase in the dry leaf yield. However, the dry leaf yields obtained at 23, 46 and $69 \mathrm{~kg} \mathrm{~N}$ ha-1 were in statistical parity (Table 3). Confirming the results of this study, Rashid et al. (2013) reported that dry leaf yield increased significantly at $60 \mathrm{~kg} \mathrm{~N} \mathrm{ha}^{-1}$ compared to the control treatment. Conduct experiment at Egypt also showed a significant increase in dry leaf biomass yields of Stevia when nitrogen fertilizer was increased from 10 to $30 \mathrm{~kg} \mathrm{~N} \mathrm{ha}^{-1}$ wherein the dry leaves yield increased by 64 percent compared to a lower dose (Allam et al., 2001). This result is in contradictory with that of Aladakatti, et al. (2012) who reported that dry leaf yield increased significantly from 9.5 to $11.42 \mathrm{t} \mathrm{ha}^{-1}$ due to increased nitrogen application from 200 to $400 \mathrm{~kg} \mathrm{~N} \mathrm{ha}^{-1}$. Increased dry leaf yield was also reported by Shock (1982a) in Japan with a moderate application of nitrogen, phosphorus, and potassium. 


\subsection{Fresh Above-Ground Biomass (t ha-1)}

Fresh aboveground biomass was significantly $(\mathrm{P}<0.5)$ influenced by the main effect of nitrogen and its interaction with phosphorous. However, the main effect of phosphorous didn't affect fresh aboveground biomass weight (Table 2). Significantly maximum fresh above-ground biomass (28.34 $\left.\mathrm{tha}^{-1}\right)$ was obtained with the combined application of $23 / 30 \mathrm{NP} \mathrm{kg} \mathrm{ha}^{-1}$, which was in statistical parity with the fresh above-ground biomass obtained in response to the combined application of 23/10, 46/0, $69 / 20 \mathrm{NP} \mathrm{kg} \mathrm{ha}{ }^{-1}$. This could be attributable to the significantly maximum number of branches per plant and fresh leaf weight obtained that contribute to the higher fresh above-ground biomass weight. The lower fresh above-ground biomass weight was recorded at nil rates of NP kg ha ${ }^{-1}$ and $0 \mathrm{~N} \mathrm{~kg} \mathrm{ha}^{-1}$ combined with all rates of phosphorous application as well as at the combined application rates of $23 / 0,46 / 10,46 / 20,46 / 30,69 / 0,69 / 30 \mathrm{NP} \mathrm{kg} \mathrm{ha}^{-1}$. Increasing rates of nitrogen from 23 to 46 and $69 \mathrm{~N}$ $\mathrm{kg} \mathrm{ha}^{-1}$ the result was not constant. With increasing nitrogen application rates, the fresh aboveground biomass increased, and this increase was observed only at the combined application of 46/0 NP kg ha${ }^{1}$ and with the combined application of $69 / 20 \mathrm{NP} \mathrm{kg} \mathrm{ha}^{-1}$ the results were inconsistent. The higher rate of nitrogen might have resulted in more vigorous plant growth, particularly information phase or vegetative growth, such as stem, and leaf. A similar result was reported by Aladakatti, et al. (2012) increased fresh above-ground biomass with the nutrient level of $400 \mathrm{~N} \mathrm{~kg} \mathrm{ha}{ }^{-1}$ and $200 \mathrm{Pkg} \mathrm{ha}^{-1}$. Maheshwar (2005) also reported that the application of 105:30:45 kg NPK/ha recorded significantly higher above-ground biomass due to a maximum number of leaves per plant and branches per plant as compared to lower doses of nitrogen and phosphorous.

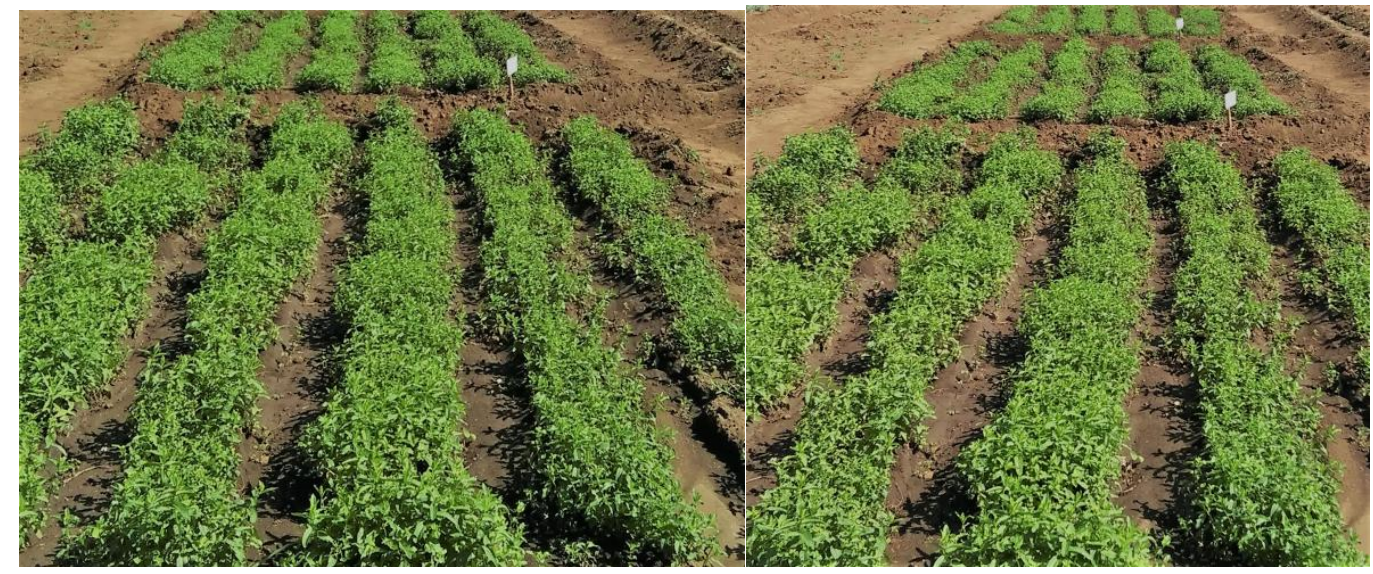

Fig. Field status during experimental period

\section{CONCLUSION}

It could be concluded that the two consecutive study years result showed that nitrogen and phosphorus application significantly increased growth and biomass yield of Stevia. The optimum economic fresh leaf yield (19.29 tha-1) and dry leaf yield $\left(4511 \mathrm{~kg} \mathrm{ha}^{-1}\right)$ were obtained in response to the combined application of $23 \mathrm{~N} \mathrm{~kg} \mathrm{ha}^{-1}$ with $10 \mathrm{Pkg} \mathrm{ha}^{-1}$. Therefore; around Menagesha and similar agroecology, soil nutrients condition should apply $23 \mathrm{~kg} \mathrm{ha}^{-1}$ nitrogen $+10 \mathrm{~kg} \mathrm{ha}^{-1}$ phosphorus to optimize the economic yield of Stevia.

\section{ACKNOWLEDGMENT}

We would like to acknowledge Land and Water Resource Research Directorate and Wondo Genet Agricultural Research Center for providing all the necessary facilities and supports during the entire experimentation. Our sincere appreciation goes to Belist Lulie Begna Bekele, Abush Yoseph, Zerihun Jonba and, for their help in field and laboratory works.

\section{REFERENCES}

[1] Kumar VR, Medicinal and Aromatic Plants. Green Cross Media International, Bangalore. pp. 90-91 (2002).

[2] Shock CC, Rebaudi's natural non-caloric sweeteners, Cal Agric 36; 4-5 (1982).

[3] Hardjowigeno, S., Soil science (Akademika Pressindo, 7th copies, Jakart (2010).

[4] Day, P.R., Hydrometer method of particle size analysis. In: C.A. Black (ed.). Methods of soil analysis. American Society of Agronomy, Wisconsin Argon. No.9. Part 2. Pp. 562-563 (1965). 
[5] Dewis, J. and Freitas P., Physical and chemical methods of soil and water analysis. FAO Bull. No.10, Rome. 271p (1970).

[6] Olsen, S.R. and Dean L.A., Phosphorus. In: Methods of soil analysis. Agronomy No 9. (1965). American Society of Agronomy. Madison, USA.

[7] SAS, Version 9.0 Institute inc., Cary, NC, USA (2002).

[8] Tekalign Tadesse, Soil, plant, water, fertilizer, animal manure and compost analysis working document. No 13. International Livestock Research Center for Africa (ILCA). Addis Ababa (1991).

[9] Landon, J.R. (Ed), Booker Tropical Soil Manual. A handbook for soil survey and agricultural land evolution in the tropics and subtropics. Longman Scientific and Technical. Essex, New York. 474p (1991)

[10] Amar, B., Diagnosis and prescription of phosphate fertilization within the Mediterranean region countries. In: African Crop Science Society Proceedings. Casablanca, 10-14 October 1999. Pp. 99-106 (1999).

[11] Aladakatti, Y. R., Palled Y. B., Chetti M. B., Halikatti S. I., Alagundagi S. C., Patil P. L., Patil V. C. and Janawade A. D., Effect of nitrogen, phosphorus and potassium levels on growth and yield of stevia (Stevia rebaudiana Bertoni). Karnataka. J. Agric. Sci., 25(1), 25-29 (2012).

[12] Chalapathi, M. V., Kumar, N. D., Rao, G. G. E. and Jayaramaiah, R., Comparative performance of plant and ratoon crops of stevia. Indian Agril., 43: 211-212 (1999).

[13] Inugraha, M. D. Maghfoer and Widaryanto E., The response of Stevia (Stevia rebaudiana Bertoni M) To Nitrogen and Potassium Fertilization. J. Agric. and Vet. Sci. Vol. (7), PP 47-55 (2014).

[14] Rashid Z., Rashid, M. Inamullah, S. Rasool S. and. Bahar F. Ah , Effect of different levels of farmyard manure and nitrogen on the yield and nitrogen uptake by stevia (Stevia rebaudiana Bertoni) Punjab, India Afr. J. Agric. Res. Vol.8(29), pp. 3941-3945 (2013).

[15] Allam, A. I., Nassar, A. M. and Besheit, S. Y., nile.enal.sci.eg/ Arc Journal/uga.htm (2001).

[16] Maheshwar HM., Effect of different levels of nitrogen and dates of planting on growth and yield of stevia (Stevia rebaudiana). M.Sc Thesis. Department of horticulture, University of agricultural sciences, Dharwad, Karnataka, India. P.100 (2005).

Citation: Nebret Tadesse, "The Response of Stevia (Stevia Rebaudiana L.) to Nitrogen and Phosphorous Fertilizer Rates at Menagesha, West Ethiopia” International Journal of Research Studies in Agricultural Sciences (IJRSAS), 2019; 5(10), pp. 34-39, http://dx.doi.org/10.20431/2454-6224.0510005

Copyright: (C) 2019 Authors. This is an open-access article distributed under the terms of the Creative Commons Attribution License, which permits unrestricted use, distribution, and reproduction in any medium, provided the original author and source are credited. 